\title{
THE URGENCY OF CLASSICAL LEARNING MOTIVATION IN THE MILLENNIAL ERA: AL-ZARNUJI'S PERSPECTIVE
}

\author{
Torikhul Wasyik ${ }^{1}$, Abdul Muhid ${ }^{2}$ \\ Pascasarjana Universitas Islam Negeri Sunan Ampel Surabaya, Indonesia ${ }^{1,}$ \\ Fakultas Psikologi dan Kesehatan Universitas Islam Negeri Sunan Ampel Surabaya, Indonesia ${ }^{2}$ \\ thorikkhoir83@gmail.com, Abdulmuhid@uinsby.ac.id
}

Received: 18-06-2020 Revised: 29-09-2020 Accepted: 12-10-2020

\begin{abstract}
Student learning outcomes in the millennial era have experienced a decline in learning achievement. Among them is a lack of motivation in students, and many Islamic boarding schools in Indonesia use ta'lim muta'allim in their lessons to motivate their students. This article aims to identify and summarize the motivation conveyed by Imam Zarnuji in the Book of ta 'im mutaalim which is suitable for the millennial era. The research method used is a descriptive qualitative method using literature studies. Data techniques by conducting studies of books, notes, article journals, notes that support each other. Data sources are divided into several types, namely: a) Primary data from the Book of ta'lim muta 'allim by Imam Al-Zarnuji b) Secondary data is complementary data that can be used as a reference in journals including relevant literature. This article results indicate that the past (Imam zarnuji) motivation is useful for the millennial era 1) Twenty-eight intrinsic motivations include Intention, patience, sincerity, and high aspirations. 2) seven extrinsic incentives should seek knowledge, find teachers and good friends, and stay away from immorality. Suggesting further research to measure what percentage of intrinsic and extrinsic motivation can increase achievement and enthusiasm for learning.
\end{abstract}

Keywords: Learning Motivation, Ta'lim Al-Muta'allim, Extrinsic And Intrinsic Motivations,

\section{Abstrak}

Hasil belajar siswa di era Milenial mengalami penurunan prestasi belajar. Diantaranya adalah kurangnya motivasi pada siswa. Dan banyak pesantren di Indonesia yang menggunakan ta'lim muta'allim dalam pembelajarannya untuk memotivasi siswanya. Penelitian ini bertujuan untuk. mengetabui dan merangkeum motivasi yang disampaikan oleb Imam Zarnuji dalam kitab Mutallim taklim yang cocok untuk era milenial. Metode penelitian yang digunakan adalah metode kualitatif deskriptif dengan menggunakan studi literatur. Teknik data dengan melakukan studi terbadap buku, catatan, catatan yang saling mendukung. Sumber data dibedakan menjadi beberapa jenis, yaitu: a) Data primer dari kitab Ta'lim Muta 'allim karangan Imam Al-Zarnuji b) Data sekunder merupakan data pelengkap yang dapat dijadikan acuan dalam jurnal termasuk literatur yang relevan. Hasil penelitian ini menunjuk.kan bahwa motivasi masa lalu (Imam zarnuji) bermanfaat bagi era milenial 1). Dua pulub delapan motivasi intrinsik meliputi Niat, kesabaran, ketulusan, dan cita-cita yang tinggi. 2). tujub motivasi ekstrinsik mencakup kewajiban untuk mencari pengetahuan, menemukan guru dan teman baik, serta menjaubi perbuatan amoral. Saran untuk, penelitian lebih lanjut agar dapat mengukur berapa persen motivasi intrinsik dan ekstrinsik yang dapat meningkatkan prestasi dan semangat belajar.

Kata Kunci: Motivasi Belajar, Kitab Ta'lim Al-Muta'allim, Motivasi Ekestrnsik dan Intrinsik. 


\section{INTRODUCTION}

In the era of millennial like this we still find a lot of students in an educational institution where they often feel lazy doing school work, always ignoring homework assignments, even if they do assignments, we find a lot of their learning results are messy and many mistakes, it all happened among them due to lack of motivation to learn ${ }^{1}$.

It all shows that the serious interest in learning began to decline drastically that occurred in the millennial era, especially in Indonesia, which is addicted to the internet which is misused, not just to seek information related to science. Millennial generation tends to behave pragmatically and instantaneously. Millennials are a group of people born in the 19802000 s range. This means that millennials are the younger generation aged 17-37 this year. ${ }^{2}$

Although it cannot be denied, humans have very general intellectual advantages (intelligence) and special advantages (talents) that are not possessed by others. But without encouragement and motivation these two things are less able to make an impact in him, especially in teaching and learning. ${ }^{3}$ No matter how smart the person is if there is no Motivation, learning will certainly fail ${ }^{4}$.

Motivation is very important for an interest in learning it is certain that learning will fail, but no matter how stupid the person is if pushed and motivated continuously then sooner or later he will be able to reach his goals ${ }^{5}$. A student because without motivation results in not achieving the maximum learning outcomes, even reaching the peak of failure. As we know from many students lately they seem to go to school every day to study, but in reality, at school, they are just silent and inactive, when the teacher is explaining the lessons they sleep. When in fact all students are able if there is encouragement inside or outside.

Motivation can be defined as a person's strength which can lead to a level of willingness to carry out an activity. Willingness either comes from within the individual himself (intrinsic motivation) and from outside the individual (extrinsic motivation) ${ }^{6}$. How strong an individual's motivation will determine the quality of the behavior he displays, both

${ }^{1}$ Shih-Yuan Huang, Yi-Han Kuo, dan Hsueh-Chih Chen, “Applying Digital Escape Rooms Infused with Science Teaching in Elementary School: Learning Performance, Learning Motivation, and Problem-Solving Ability," Thinking Skills and Creativity 37 (1 September 2020): 100681, https://doi.org/10.1016/j.tsc.2020.100681; Hayward P. Andres, "Active teaching to manage course difficulty and learning motivation," Journal of Further and Higher Education 43, no. 2 (7 Februari 2019): 220-35, https://doi.org/10.1080/0309877X.2017.1357073.

2 Mahyuddin Barni, “Tantangan Pendidik Di Era Millennial," Transformatif 3, no. 1 (24 April 2019): 99_ 116, https://doi.org/10.23971/tf.v3i1.1251.

${ }^{3}$ Purwanto Ngalim, Psikologi Pendidikan, 27 ed. (Bandung: Remaja Rosdakarya, 2014), 61.

4 Xiaolu Zhou dan Ling Tian, "Study on learning motivation for innovative talents of local normal universities," Journal of Interdisciplinary Mathematics 20, no. 6-7 (3 Oktober 2017): 1401-5, https://doi.org/10.1080/09720502.2017.1382145.

5 David C. McClelland, Human Motivation, Re-issued in this digitally printed version (Cambridge: Cambridge University Press, 2009); Amiruddin Siahaan, Tien Rafida, dan Khairunnisa Batubara, "Influence of Madrasah Head Leadership, Motivation and Madrasah Culture on Teacher Performance in Madrasah Aliyah Model 2 Medan," Budapest International Research and Critics Institute (BIRCI-Journal): Humanities and Social Sciences 3 (3 Agustus 2020): 2174-82, https://doi.org/10.33258/birci.v3i3.1150.

${ }^{6}$ Jonathon E Larson, Educational Psychology: Cognition and Learning, Individual Differences and Motivation (New York: Nova Science Publishers, 2009), http://public.eblib.com/choice/publicfullrecord.aspx?p=3018385. 
in the context of learning, work, and in other lives. The learning process will be successful when students have the motivation to learn.

So, eventually, it will lead to many underdeveloped children's talents due to not getting strong motivation and encouragement. So if only one student gets a lot of encouragement from educators, then the extraordinary energy will be released stored in each student that has hidden potentials, so that unexpected results will be achieved into a reality. Many of us see students when we see them in their class silent and not brave, but after a few years when he was at the college level and has mingled with many people and a different atmosphere ${ }^{8}$. The student grew very active, even more daring to convey arguments, ideas, and have abilities that we had not previously seen. Then the actual learning outcomes are determined by how much encouragement or motivation of educators towards students. Motivation is not only important because it is a factor that causes learning but also makes learning easier and learning outcomes. ${ }^{9}$

According to Dimyati and Mudjiono" learning outcomes are things that can be seen and measured from two sides, namely from students and educators, from the student side learning outcomes are characterized by a level of development and mental change compared to before learning." ${ }^{10}$ If there is no progress in the learning outcomes then it means that the student did not achieve the learning process properly ${ }^{11}$. As for the side of the success of educators in delivering their learning, including the accuracy of teachers in choosing teaching materials, unique and interesting media, as well as innovative, creative and fun teaching methods that cause the learning process in the class to run well, eventually all students can feel happy, comfortable and understand the material being studied ${ }^{12}$.

In conclusion, motivation is very important and encouraging for someone to be able to complete a goal that he wants to do. By knowing the goals and benefits, it will get stronger and more eager to do it. ${ }^{13}$ If he is a student who already knows the benefits of learning, it will be easy to achieve what he has dreamed of. As a result, everyone will not feel lazy in the learning process ${ }^{14}$.

${ }^{7}$ Siti Suprihatin, "Upaya Guru Dalam Meningkatkan Motivasi Belajar Siswa," Promosi: Jurnal Program Studi Pendidikan Ekonomi 3, no. 1 (2015), https://doi.org/10.24127/ja.v3i1.144.

8 Cornelius Brandmiller, Hanna Dumont, dan Michael Becker, "Teacher Perceptions of Learning Motivation and Classroom Behavior: The Role of Student Characteristics," Contemporary Educational Psychology, 11 Juni 2020, 101893, https://doi.org/10.1016/j.cedpsych.2020.101893.

${ }_{9}$ Rizki Sobandi, "Pengaruh Motivasi Belajar Terhadap Hasil Belajar Bahasa Indonesia Pada Siswa Kelas Viii Mts Negeri 1 Pangandaran,” DIKSATRASLA 1, no. 2 (31 Agustus 2017): 306-10, https://jurnal.unigal.ac.id/index.php/diksatrasia/article/view/634.

10 Dimyati dan Mudjiono, Belajar dan pembelajaran (Jakarta: Rineka Cipta, 1999).

11 Dr. Jeanine M. M Dell'Olio dan Dr. Tony Donk, Models of Teaching: Connecting Student Learning with Standards. (Thousand Oaks: SAGE Publications, 2007), http://public.eblib.com/choice/publicfullrecord.aspx?p=996882.

12 B. R Hergenhahn dan Matthew H Olson, Theories of learning = teori belajar, trans. oleh Triwibowo, 6 ed. (Jakarta: Prenada Media Grup, 2016).

13 Ngalim, Psikologi Pendidikan, 9.

14 Muhammad Anas Ma'arif, "Analisis Konsep Kompetensi Kepribadian Guru PAI Menurut AzZarnuji," ISTAWA 2, no. 2 (2017): 35-60, http://journal.umpo.ac.id/index.php/istawa/article/view/624; Siti Mariah Ulfah, "Rekrutman Guru Dalam Manajemen Pendidikan Islam (Studi Tentang Pemilihan Guru Menurut Syeikh Az- Zarnuji Dalam Kitab Ta’limul Muta'allim Wathoriqotutta'allumi)," Al-Fikrah: Jurnal Kependidikan Islam 
After someone has been motivated to do the learning process, finally he will get the results of the achievement of the learning process. These results are called learning achievements. Learning achievement is the result of the development of the level of psychological domains as a result of students' learning experiences and processes achieved within a certain period ${ }^{15}$. Because with a good learning achievement, actually it can be used to see and measure the level of ability and quality of a student. A big nation is not judged by the size of the location of the country and the source of wealth in its possession. Because the greatness of a nation is determined by the quality of its human resources and the nation's ability itself. ${ }^{16}$

That contains the motivation to learn accompanied by stories of previous scholars makes the imagination of the students to be carried in the rhythm and message conveyed ${ }^{17}$. Both in terms of how to learn, the Intention to seek knowledge, how to find a teacher, when to start to learn, when to manage learning time, how can a person achieve success in the world until the hereafter later ${ }^{18}$. It was all expressed in the Book of ta'lim muta'allim with an interesting story style. Even though the Book was taught many times from year to year, it did not detract from the love of students and students to learn it, because this Book is very multicontent with motivations that are needed by students and students ${ }^{19}$.

Until in the Modern era like today, the ta' lim al-muta'allim Book is considered as one of the main reference books in changing and making students be successful in times of seeking knowledge both the world and the hereafter. ${ }^{20}$ Seen from the previous scholars and Muslim scholars and cultural figures in the millennial era like this. They are remembered by the State and Religion including Kiai Hasyim Asy'ari Jombang, KH. Kholil Bangkalan, Gus Dur, Muhammad Ainu Nadjib, or Cak Nun and other scholars who all of them had studied the Book of ta' 'im al-muta'allim ${ }^{21}$. They are one of the few scholars in the archipelago that have proven successful inside study. The learning process that they traveled has experienced various extraordinary tests. But the spirit of motivation that is in them and the encouragement

LAIN Sulthan Thaha Saifuddin 6 (2015), https://www.neliti.com/publications/56675/rekrutman-guru-dalammanajemen-pendidikan-islam-studi-tentang-pemilihan-guru-men.

15 Muhibbin Syah, Psikologi Pendidikan dengan pendekatan baru, 18 ed. (Bandung: Remaja Rosdakarya, 2013), 55.

16 E Mulyasa, Manajemen Pendidikan Karakter, 5 ed. (Jakarta: Bumi Aksara, 2016); Zubaedi, Desain Pendidikan karakter, Konsepsi dan Aplikasinya dalam Pendidikan (Jakarta: Kencana Prenada, 2011).

17 Isnaeni Isnaeni, "Konseling Behavioral Berbasis Kitab Ta'lim al-Muta'allim Untuk Meningkatkan Motivasi Belajar Santri Di Pondok Pesantren Tafsir Hadis Shohihuddin 2, Prapen Surabay, Jawa Timur" (undergraduate, UIN Sunan Ampel Surabaya, 2019), http://digilib.uinsby.ac.id/30215/.

18 Muhammad Barmawi, "Peranan Lingkungan terhadap Semangat Belajar dalam Khazanah Kitab Kuning," Edukasia Islamika, 2 Maret 2017, 134-60, http://ejournal.iainpekalongan.ac.id/index.php/edukasiaislamika/article/view/773.

19 Rizqiyatul Muyassaroh, "Pengaruh Aktivitas Santri Dalam Pembelajaran Kitab Ta'lim al-Muta'allim Terhadap Motivasi Belajar Agama Santri Ma’had al-Jami'ah Walisongo Semarang” (undergraduate, UIN Walisongo Semarang, 2019), http://eprints.walisongo.ac.id/9591/.

${ }^{20}$ Rudi Ahmad Suryadi, "Motivasi Belajar Perspektif Pendidikan Islam Klasik: Studi atas Pemikiran alJarnuji," Jurnal Pendidikan Agama Islam-Ta' lim 10, no. 1 (2012).

21 Effendi Chairi, "Pengembangan Metode Bandongan Dalam Kajian Kitab Kuning Di Pesantren Attarbiyah Guluk-Guluk Dalam Perspektif Muhammad Abid al-Jabiri," Nidhomul Haq: Jurnal Manajemen Pendidikan Islam 4, no. 1 (15 Maret 2019): 70-89, https://doi.org/10.31538/ndh.v4i1.233. 
of the teachers, their parents prove able to achieve knowledge that is beneficial to these people.

So the library research on the Book of ta'lim al-muta'allim is expected to be able to record and summarize the Collection of Motivation conveyed by Imam Zarnuji starting from the beginning to the end of the Book so that this motivation can be used as supplementary material for the current generation to always be enthusiastic in seeking knowledge that can bring blessings to life both the world and the hereafter.

\section{METHOD}

In this study, the authors apply the method of library research because there are at least some underlying reasons. First, the source of the research was not obtained by field research. But data sources are only obtained through library studies or other documents in written form, whether from journals, books, or other literature ${ }^{22}$. Secondly, library study is needed as a way to solve problems that occur in the millennial era like this by using alternative classical methods found in library sources, so that this literature study can be applied in overcoming problems faced with. Third, library data is considered as one of the main sources as a very strong and reliable reference material to be used as a source of research material.

The research uses data sources from various sources relevant to the discussion of this journal. The data source is divided into several types, namely: a) Primary Data is a basic source obtained through the study of a book entitled ta'lim al-muta'allim by Imam Al-Zarnuji b) Secondary data is supplementary data or support that has been arranged well and can be used as a reference in journal writing, the data includes literature that is relevant to the object of research in the form of books, papers, scientific articles, journals, theses, ebooks, and others ${ }^{23}$.

Data analysis is carried out using of the following methods: a) Descriptive method is a research method to describe complitely the symptoms, events, events that occur at present regularly, and examines an object of research concerning motivation to learn that is inside the Book of ta 'lim al-muta'allim. b) Content analysis method is a method of studying and analyzing data systematically and objectively by analyzing the data that has been collected and then the data is classified in a motivational group that arises either from within or from outside. Weber explained that the content study is a research that has phases in finding a correct conclusion both from books and other documents. So in fact the data analysis stage is a series of collected data that is developed and processed in a simple framework to conclude.

\section{Biography of Imam Zarnuji}

Imam Zarnuji's full name is Burhanuddin Ibrahim al-Zarnuji al-Hanafi, he is a writer who came from Bukhara. ${ }^{24}$ And some say his name is Tajuddin bin Ibrahim bin Al-Khalil Zarnuji. ${ }^{2526} \mathrm{He}$ was born around 570 Hijriyah. ${ }^{27}$ Maryati quotes Djudi's opinion that Imam

22 Mestika Zed, Metode penelitian kepustakaan, Ed. 2 (Jakarta: Yayasan Obor Indonesia, 2008).

23 Barbara M. Wildemuth, Applications of social research methods to questions in information and library science (Westport, Conn: Libraries Unlimited, 2009).

${ }^{24}$ Louwis Ma'luf, Munjid Fillughah Wal 'lam (Bairut libanon: Dar Al-Masyrik, 1975).

25 Maslani Maslani dkk., "Al-Zarnuji's Thought of Education and Its Implementation at Pesantren," Jurnal Pendidikan Islam 3, no. 2 (1 Januari 2018): 179-90, https://doi.org/10.15575/jpi.v3i2.1312; Benny Afwadzi dan Abdul Fattah, "Pemahaman Hadits Tarbawi Burhan al Islam al Zarnuji Dalam Kitab Ta'lim al Muta'allim," Ulul Albab 17, no. 2 (1 Januari 2017): 197-217, https://doi.org/10.18860/ua.v17i2.3831.

${ }^{26}$ Burhanul Islam Al-Zarnuji, Ta 'imul Muta alim (Surabaya: Al-Hidayah, t.t.). 
Zarnuji learned to study from Bukhara to Samarkand where both cities were centers of science and teaching. ${ }^{28}$ He was a follower of the Hanafi School of Law, as evidenced in many of his arguments in the taklim Mutallim book which he composed almost on average mentioning Imam Abu Hanifa as his reference. ${ }^{29}$ Imam Zarnuji is a medieval education figure who explains about one's learning goals not only to pursuing worldly satisfaction but to the hereafter. ${ }^{30}$ His writing is very much, both in the fields of fiqh, language and literature which is Hanafi school of thought. ${ }^{31}$

The most famous teachers include 1. Burhanuddin Ali bi Abi Bakar Al Marghinani $(593 \mathrm{H} / 1197)$ an author of Al Hidayah which is the main reference in the Al Hanafi School. 2. Ruknul Islam Muhammad bin Abi Bakar (573H / 1177), a mufti in the Bukhora area. 3. Hamad bin Ibrahim $(576 \mathrm{H} / 1180)$, a writer, jurisprudence and knowledge of tawheed 4. Fakhrudin Al kasyani a judge in the Khon area (587H./1191), Author of the book 'Storm' Al Shanai ' 5. Ruknudin Al-Farghani (594H / 1198) an expert on figh, and poetry. ${ }^{32}$ The exact year of his death is unknown because there are many different sources, one of which explains that Imam Zarnuji died in $591 \mathrm{AH}, 593 \mathrm{AH}$ and 597 Hijriyyah. But a strong opinion was in $620 \mathrm{H} . / 1932 \mathrm{M}^{33}$

\section{The Book of Ta'lim Al-Muta'allim}

Ta'lim Muta'allim book is one Book that explains the attitudes and procedures that must be learned by students before seeking knowledge. According to Hasan Langgulung ${ }^{34}$ That the actual content contained in the Book of $t a^{\prime}$ lim mutaalim is not just a motivational theory of learning, but on the other hand, the Book contains a meaning that is further than that because sheik Zarnuji lived at the end of the Abbasiyah government and inherited much the advance of science. The full name of the Book of Taklim is the Book of Ta lim AlMuta'allim fi Tariqa at-Ta'allum which was written by Sheik Imam Zarnuji.

The reason why this Book is written is that in the time of Sheik Zarnuji many students sought knowledge, they were very serious in their learning process, but on the other hand, it

27 Sodiman Sodiman, "Etos Belajar Dalam Kitab Ta\&\#39;liim Al-muta\&\#39;allim Thaariq Alta\&\#39;allum Karya Imam Al-zarnuji," Al-Ta\&\#39;dib 6, no. 2 (Desember 2013): 56-72, https://www.neliti.com/publications/235741/etos-belajar-dalam-kitab-taliim-al-mutaallim-thaariq-al-taallumkarya-imam-al-za.

28 Maryati, "Konsep Pemikiran Burhanuddin Al-Zarnuji Tentang Pendidikan Islam: Telaah Dalam Perspektif Hubungan Guru Dan Murid” (Jakarta: UIN Syarif Hidayatullah, 2014).

${ }^{29}$ Ramayulis dan Samsul Nizar, Filsafat pendidikan Islam: telaab sistem pendidikan dan pemikiran para tokohnya (Jakarta: Kalam Mulia, 2009).

30 Suryadi, "Motivasi Belajar Perspektif Pendidikan Islam Klasik."

31 M. Anas Thohir, Alfina C, dan A. Dardiri, "A Comparative Study on Sheikh Az-Zarnuji Thought and Idealism in the Philosophy of Education," Episteme: Jurnal Pengembangan Ilmu Keislaman 12, no. 2 (1 Januari 2018): 411-33, https://doi.org/10.21274/epis.2017.12.2.411-433; Nur Salami dan Anton Widyanto, "Etika Hubungan Pendidik Dan Peserta Didik Menurut Perspektif Pendidikan Islam Dan Pendidikan Barat (Studi Komparatif Pemikiran al-Zarnuji Dan Paulo Freire)," DAYAH 1, no. 2 (1 Juli 2018): 164-81, https://doi.org/10.22373/jie.v1i2.2945.

32 Tumin Tumin dan Ahmad Faizuddin, "Education and Character Building: Ethical Aspects of Learning from Al-Zarnūjì’s Ta‘lìm Al-Muta'allim,” Ulumuna 21, no. 1 (1 Juni 2017): 109-28, https://doi.org/10.20414/ujis.v21i1.1180.

33 Binti Su'aidah Hanur dan Titik Widayati, "Character Building Di Abad 12 Masehi: Kajian Dan Analisis Pendidikan Akhlak Dalam Kitab Ta'lim Muta'Alim," Journal of Childhood Education 2, no. 2 (1 November 2019): 176-92, https://doi.org/10.30736/jce.v2i1.37.

${ }^{34}$ Hasan Langgulung, Manusia dan Pendidikan, cet ke 1 (Jakarta: Pustaka Al-Husna, 1986). 
turned out that they did not get the blessing and the benefits of the knowledge they had learned after they returned to the community. After careful examination, it turned out that it was because they left the conditions and procedures for seeking knowledge in their period of study. The Book of ta'lim muta'alim, is actually a collection of references obtained by Sheik Zarnuji both from various sources of references or from information that he got directly from his teachers. ${ }^{35}$

The subject matter of the Book of ta' 'im al-muta'allim consists of thirteen chapters of the discussion, namely: Article 1 (Regarding the a nature of knowledge, a law seeking knowledge, and its importance), Article 2 (Arranging intentions in seeking knowledge), Article 3 (On how to choose knowledge, teachers, friends, and perseverance in learning), Article 4 (how to respect knowledge and teachers), Article 5 (Concerning sincerity in seeking knowledge, having a long term and noble aspirations), Article 6 (Concerning the beginning for learning, its size and discipline), Article 7 (Tawakkal and surrender to God), Article 8 (Regarding the period of study), Article 9 (Regarding mutual love and counsel), Article 10 (taking knowledge), Article 11 (Concerning being in a state when I am studying), Article 12 (regarding matters that can strengthen memorization and weaken it), Article 13 (Regarding matters which can make it easier to bring fortune, can extend life, and reduce life). ${ }^{36}$

Of the thirteen main chapters or chapters of the discussion, Sheik Zarnuji explained the many motivations and procedures of students in seeking knowledge, outlined basis on the prophet or sometimes often taking the stories of the previous scholars to reinforce the arguments he uttered.

\section{Learning motivation in the Book of Ta'lim Al Muta'allim}

Imam Zarnuji in the Book of ta'lim mutaalim has explained many motivations for student, or santri to succeed in finding knowledge to gain good fortune in the world and the hereafter. ${ }^{37}$ The good motivation that comes from within yourself or from outside. The author of this study wants to explore motivations according to the Book of ta'lim mutaalim that arises from his personalities, such as the desire to meet the basic needs he needs, or motivation that comes from outside such as motivation from friends, teachers, and the environment ${ }^{38}$.

Here are some of the learning motivations contained in his personality (internal) or from outside (external) contained in the Book ta'lim al-muta'allim written by Sheik Burhanuddin Imam Zarnuji:

35 Alfianoor Rahman, "Pendidikan Akhlak Menurut Az-Zarnuji Dalam Kitab Ta'lim al-Muta’allim," AtTa'dib 11, no. 1 (1 Juni 2016), https://doi.org/10.21111/at-tadib.v11i1.647.

36 Ulfah, "Rekrutman Guru Dalam Manajemen Pendidikan Islam (Studi Tentang Pemilihan Guru Menurut Syeikh Az- Zarnuji Dalam Kitab Ta’limul Muta'allim Wathoriqotutta'allumi).”

37 Agus Setiawan, "Prinsip Pendidikan Karakter Dalam Islam: Studi Komparasi Pemikiran Al-Ghazali Dan Burhanuddin Al-Zarnuji," Dinamika Ilmu 14, no. 1 (1 Juni 2014): 1-12, https://doi.org/10.21093/di.v14i1.4.

38 Zainal Arifin, "Lingkungan Pendidikan Berperan Aktif Menumbuhkan Motivasi Belajar Siswa Menurut Syaikh Al-Zarnuji, Dalam Kitab Ta’limul Muta'allim," Al Qodiri: Jurnal Pendidikan, Sosial dan Keagamaan 7, no. 2 (2014): 32-40. 


\section{Motivation arising from his own personality (internal)}

Table 1. Motivation arising from his personality

\begin{tabular}{|c|c|c|c|}
\hline No. & Internal Motivation & article & editor in the Book \\
\hline 1. & $\begin{array}{l}\text { People who have } \\
\text { knowledge will be more } \\
\text { noble than animals, or } \\
\text { angels }\end{array}$ & 1 & 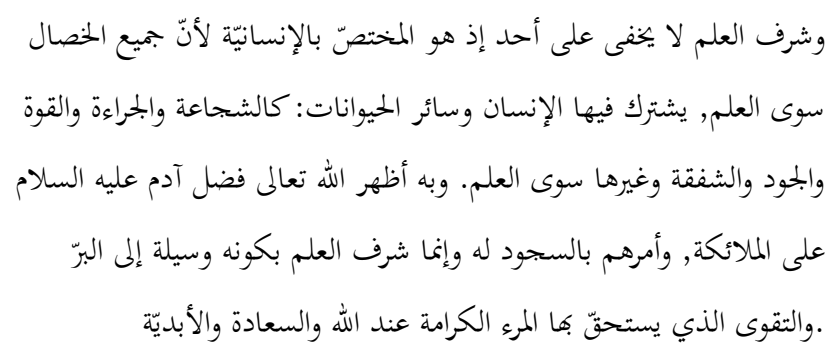 \\
\hline 2. & $\begin{array}{l}\text { Good intentions are the } \\
\text { key to success and } \\
\text { success }\end{array}$ & 2 & 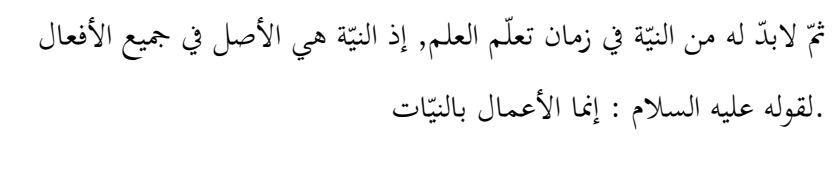 \\
\hline 3. & $\begin{array}{l}\text { Deliberation will make } \\
\text { matters easy and the } \\
\text { results satisfactory }\end{array}$ & 3 & 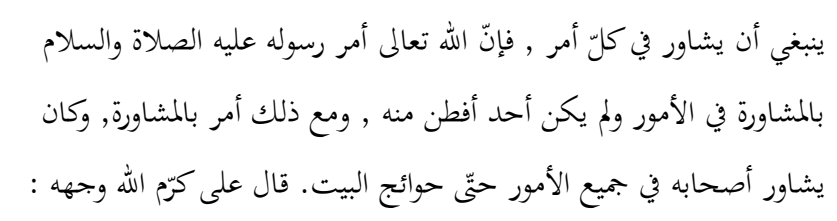 \\
\hline 4. & $\begin{array}{l}\text { Patience and } \\
\text { perseverance are the } \\
\text { basis of all things }\end{array}$ & 3 & 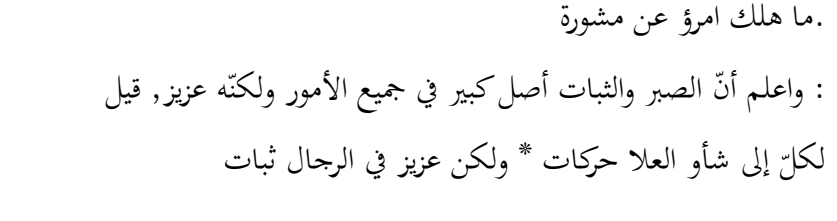 \\
\hline 5. & $\begin{array}{l}\text { By being serious } \\
\text { anything will be easy }\end{array}$ & 5 & الكرّة لا بدّ من الجدّ والمواظبة والملازمة لطالب العلم , وإليه الإشارة في القرآن \\
\hline 6. & $\begin{array}{l}\text { High ideals will deliver } \\
\text { a real dream }\end{array}$ & 5 & 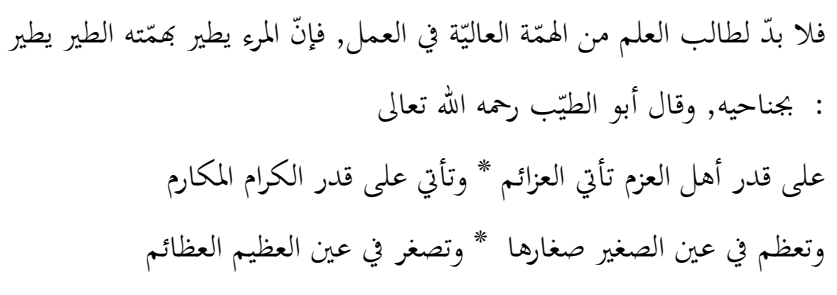 \\
\hline 7. & $\begin{array}{l}\text { Science will be eternal, } \\
\text { even if it has passed } \\
\text { away }\end{array}$ & 5 & 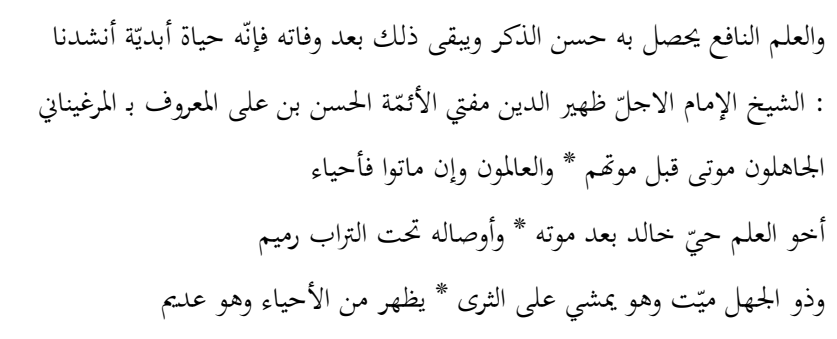 \\
\hline 8. & $\begin{array}{l}\text { Bulghom disease in a } \\
\text { person will cause } \\
\text { someone to be stupid } \\
\text { and lazy }\end{array}$ & & و وقد يتولّد الكسل من كثرة البلغم والرطوبات طريق تقليله, تقليل الطعام ـ قيل \\
\hline
\end{tabular}


9. By noting knowledge a lot of benefits will be obtained

10. By often thinking will be able to find the problems at hand

11. With munadharah, deliberation and mudzakarah, the truth can certainly be obtained

12. The lack of money in his life cannot be used as an excuse for not seeking knowledge

13. By always being grateful, Allah will always add to his pleasure

14. Stingy nature is the key to failure, and

Generosity is the key to success
6

$$
\begin{aligned}
& \text { وينبغي أن يعلّق السبق بعد الضبط والإعادة كثيرا, فإنّه نافع جدّ. ولايكتب } \\
& \text { المتعلّم شيأ لايفهمه, فإنّنه يورث كلالة الطبع ويذهب الفطنة ويضيّع أوقاته }
\end{aligned}
$$

وينبغي أن يجتهد في الفهم عن الأستاذ بالتأمّل وبالتفكير وكثرة التكرار, فيإنّه إذا $\quad 6$

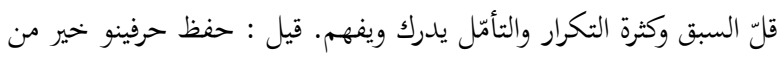
سماع وقرين, وفهم حرفين خير من حفظ سطرين. وإذا تماون في الفهم ولم

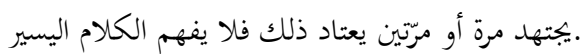

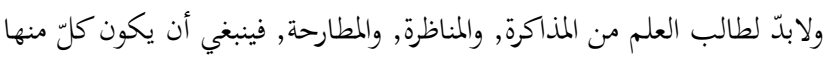
بالإنصاف والتأني والتأمل, يتحرز عن الشغب أي الغضب , فإنّ المناظرة

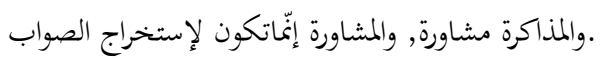

وليس صحيح العقل والبدن عذر في ترك التعلّم والتفقه, فإنّه لايكون افقر من أبي يوسف, ولم يمنعه ذلك من التفقه وليد

6

$$
\begin{aligned}
& \text { من كان له مال كثير فنعم المال الصالح للرجل الصالح, المنصرف في طريق }
\end{aligned}
$$

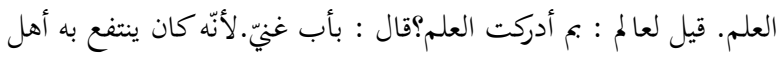

$$
\begin{aligned}
& \text { العلم والفضل, فإنّه سبب زيادة العلم لأنّه شكر على نعمة العقل والعلم, وإنّه } \\
& \text { : }
\end{aligned}
$$

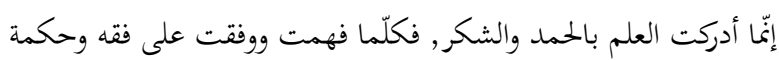

$$
\begin{aligned}
& \text { قلت :الحمد لله, فازداد علم }
\end{aligned}
$$

6

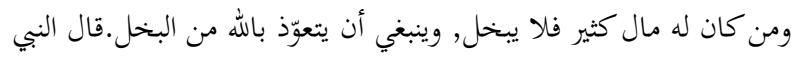

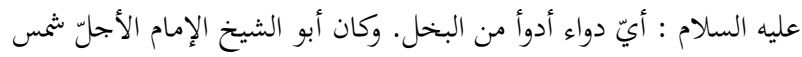

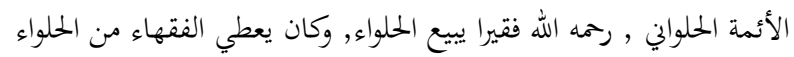
ويقول : ادعوا لابني, فبركة جودة واعتقاده وشفقته وتضرعه إلى الله تعالى نال ابنه مانال

15. Tama' 'or hope that والعالم إذا كان طماعا لا يبقى له حرمة العلم ولايقول بالحقّ ولهذا كان يتعوّذ

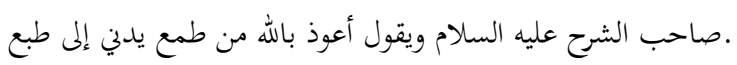
destroy himself

16. Tawakeal is the key to 
success

$$
\text { قرلبه بذلك. روى أبو حنيفة رحمه الله عن عبد الله بن الحارث الزبيدي صاحب الله صلى الله عليه وسلّم : من تفقه في دين الله كفى همّه الله تعالى ورزقه }
$$

17. A heart that is troubled and agitated at the thought of worldly affairs will prevent a person from achieving high glory

18. By enduring all the trials will be able to obtain glory

19. Patience in learning is the key to achieving the joy of knowledge

20. Affection will instill the existence of benefits to himself and others

21. The perfection of knowledge can be achieved by studying every day

22. Studying with people who are older or more experienced will lead to the perfection of their knowledge

23. Other people's knowledge can be obtained by humbling themselves to him

24. The nature of $W$ ara 'or be careful of cases that are doubtful will keep away from disaster

25. By doing Adab and

7

7

$$
\begin{aligned}
& \text { فإنّ من اشتغل قلبه بأمر الرزق من القوت والكسوة قلّ ما يتفرغ لتحصيل }
\end{aligned}
$$

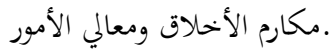

$$
\begin{aligned}
& \text { قيل : دع المكارم لاترحل لبغيتها " واقعد فإنّك أنت الطاعم الكاسي }
\end{aligned}
$$

ولابدّ من تحمل النصب والمشقة في سفر التعلم, كما قال موسى صلوات الله على الله على نبيّا وعليه في سفر التعلم ولم ينقل عنه ذلك في غيره من الأسفار

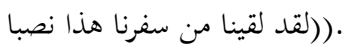

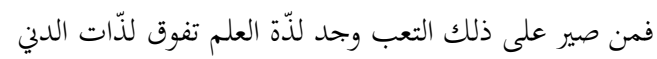
ينبغي أن يكون صاحب العلم مشفقا ناصحا غير حاسد فالحسد يضرّ

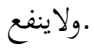
فينغي أن لايضيّع طالب العلم الأوقات والساعات ويغتنم الليالي والخلوات وينبغي أن يغتنم الشيوخ ويستفيد منهم, وليس كلّ مافات يدرك.

عن رسول الله صلى الله عليه وسلّم أنّه قال : من لم يتورع في تعلمه ابتلاه الله تعالى بأحد ثلاثة أشياء : إمّا أن يميته في شبابه, أو يوقعه في الرساتيق, أو يبتليه

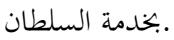




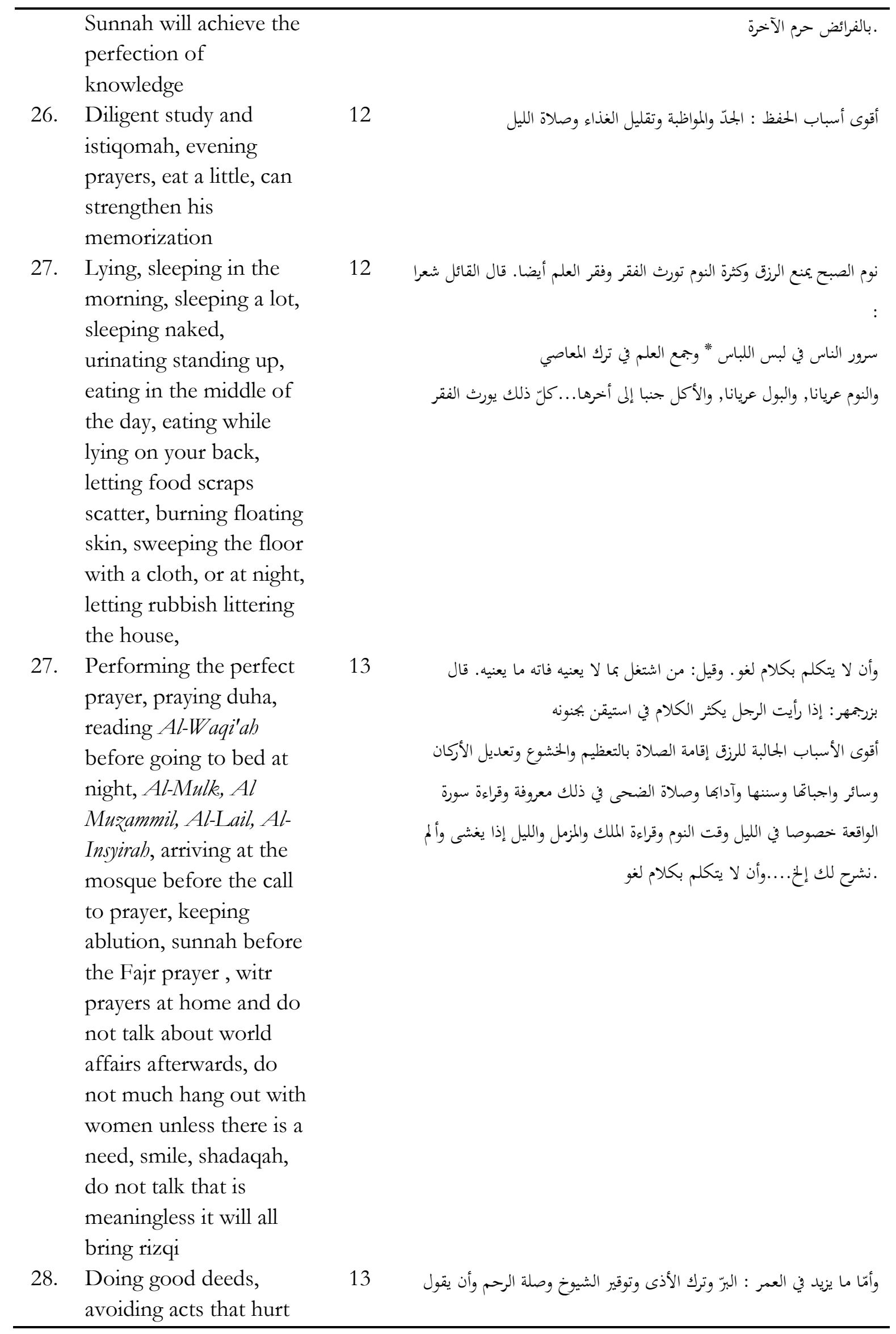


others, respecting older

حين يصبح ويمسي كلّ يوم ثلاث مرّات : سبحان الله ملء الميزان إلخ....وزنة people, friendship, praying in the morning

and evening will cause

longevity

Source: Data Analize form Talimul Mutallim Book

Motivation arising from outside oneself

Table 2 Motivation arising from outside oneself

No. Internal Motivation article

1. Prophet Muhammad SAW.

1

requires learning science

2. Good and smart friends and teachers will influence a person's learning process

3. Glorifying knowledge or books, friends, teachers and their families will lead to the blessing of their knowledge

4. The strength of Islam is by looking after yourself

5. The perfection of knowledge can be obtained Achieved a good day selection too

6. Size and methods are good for memorizing and learning

7. Doing immorality and many sins, restless in worldly affairs, Eating coriander, apples that are still sour, seeing the cross, reading the grave writing, walking on the sidelines of camel tarakit, throwing live lice to the ground, laying on the nape of the head, will cause students to become forgetful.
3

4

$$
\text { بتعظميم العلم وأهله طالب العلم لا ينال العلم ولا ينتفع به إلا }
$$

5

$$
\text { قال عليه السلام : نفسك مطيّتك فارفق .ما. }
$$

6

$$
\text { قال رسول الله صلى الله عليه وسلّم : ما من شيء بدئ. }
$$

6

$$
\begin{aligned}
& \text { وينبغي لطالب العلم أن يكرّر سبق الأمس خمس مرّزات }
\end{aligned}
$$

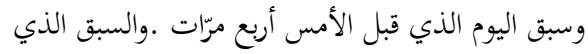

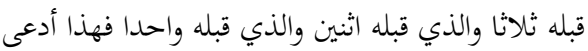

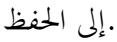

$$
\text { وأما ما يورث النسيان فهو : المعاصي وكثرة الذنوب المعط والمبان }
$$

Source: Data Analize form Talimul Mutallim Book 


\section{The Urgency of Classical Learning Motivation in The Millenial Era}

From the discussion and theory above, motivation has an important role in determining achievement and enthusiasm for learning because motivation will encourage someone to achieve goals so that the desired goals can be achieved. And if students are motivated to learn, there will be effective learning which will ultimately result in high learning achievement. In other words, the intensity of one's motivation will greatly determine the level of achievement of their learning achievement ${ }^{39}$.

In learning activities, students who are in the learning process have a strong and clear motivation, and will be diligent and successful in their learning. This is because there are three functions of motivation, namely: encouraging humans to act and carry out activities, determine the direction of their actions, and select their actions. So that students' actions are always in line with the learning goals they will achiev ${ }^{40} \mathrm{e}$.

So, motivation can be interpreted as the strength (energy) of a person which can cause a level of willingness to carry out an activity. Willingness either comes from within the individual himself (intrinsic motivation) and from outside the individual (extrinsic motivation). How strong an individual's motivation will determine the quality of the behavior he displays, both in the context of learning, work and in other life ${ }^{41}$.

The Millennial generation who are now often relied on for their role in the world of education today. It can be seen that their interest in learning has decreased drastically, because millennials, especially in Indonesia, are already addicted to the internet which is misused, not just to seek information related to science ${ }^{42}$.

The difference between this study and other research is that this study has described and classified the motivation written by Imam Zarnuji in his Ta'lim Mutaalim book, which the motivation conveyed in the Book reaches hundreds of motivations, but this research tries to reduce these motivations into two groups, namely motivation. intrinsic and extrinsic which are very influential to encourage students' enthusiasm for learning when learning.

From the explanation of the theory above, the classic motivation in the $t a^{\prime} l i m$ mutaalim book in the form of intrinsic motivation is that there are twenty-eight motivations, namely: 1). People who have more knowledge than animals and even angels 2). Good intention is the key to success and success 3). Deliberation will make things easy and good results 4). Patience and perseverance are the basis of virtue. 5) By being serious, he will get something 6). High ideals will deliver a real dream 7). Knowledge will be eternal, even after death 8). Bulghom disease in a person causes ignorance and laziness 9). Taking notes can be

39 Juni Astuti, Mona Novita, dan M. Syukri Ismail, "Peningkatan Motivasi Belajar Menggunakan Contextual Teaching and Learning Di Madrasah Ibtidaiyah Swasta Raudhatul Mujawwidin Tebo," Jurnal Educative: Journal of Educational Studies 5, no. 1 (1 Juli 2020): 16-28, https://doi.org/10.30983/educative.v5i1.1630.

40 Thohir, C, dan Dardiri, "A Comparative Study on Sheikh Az-Zarnuji Thought and Idealism in the Philosophy of Education."

41 Richard M. Ryan dan Edward L. Deci, "Intrinsic and Extrinsic Motivations: Classic Definitions and New Directions," Contemporary Educational Psychology 25, no. 1 (1 Januari 2000): 54-67, https://doi.org/10.1006/ceps.1999.1020.

42 I-Fan Liu, "The Impact of Extrinsic Motivation, Intrinsic Motivation, and Social Self-Efficacy on English Competition Participation Intentions of Pre-College Learners: Differences between High School and Vocational Students in Taiwan," Learning and Motivation 72 (1 November 2020): 101675, https://doi.org/10.1016/j.lmot.2020.101675. 
useful 10). thinkable to find the problems it faces 11). With munadharah, deliberation and mudrakarah, the truth will be easily achieved 12). Less cost should not be used as a reason for dropping out of seeking knowledge 13). Will always be thankful Allah will always add the pleasure 14). Misery is the key to failure, and generosity is the key to success 15). Tama 'or hoping that someone else's gift can destroy someone's personality 16). Tawakkal the key to success 17). A heart that is troubled and restless because of thinking about worldly affairs will lead to love of the world 18). By enduring trials will be obtained glory 19). Patience in learning will get glory 20). love for others causes the benefits of science. perfection can be achieved by studying every day 21). Learning with parents or more experienced people will have more perfect knowledge 22). Knowledge of others can be obtained by inferiority to him 23). The nature of Wara 'or being careful of true matters will keep oneself from calamity 24). By doing Adab and Sunnah you will achieve the perfection of knowledge

25). Diligent study and istiqamah, evening prayers, eat a little, and pray 'and others can strengthen memorization 26). Lying, sleeping in the morning, sleeping a lot, sleeping naked, peeing standing up, eating in a state of junub, eating on the back, letting leftovers scattered, burning onion skins, sweeping the floor with a cloth or at night, leaving the trash littering the house, passing in front of parents, calling parents by directly mentioning their names, cleaning between teeth with coarse objects, smearing dust on both hands, sitting on the porch of the door, sitting leaning against the door, ablution where people rest, sewing clothes that are in use, cleaning face with cloth, leaving cobwebs at home, lightening prayers, rushing out of the mosque after dawn prayers, going to the market in the morning, buying food from beggars, leaving containers open, turning off the lights with how to blow, write with a broken pen, do not pray for your parents well, wear a turban while standing ri, wearing pants while sitting, stingy, too thrifty, excessive in spending wealth, lazy, delaying or underestimating an affair, all of which can lead to poverty. 27). Performing prayers perfectly, praying duha, reading Surah AlWaqi'ah before going to bed at night, Reading Surah Al-Mulk, Surat Al-Murammil, Al-Lail, AlInsyirah, going to the mosque before the call to prayer is performed, keeping ablution, praying Sunnah before the Fajr prayer, praying witr at home and not talking about world affairs afterward, not hanging out with women a lot unless there is a need, smiling, shadaqah, not talking about something meaningless, it will all bring rizqi 28). Doing good, staying away from actions that hurt others, respecting elders, staying in touch, praying in the morning and evening will all cause his life to be long.

These twenty-eight are actually in line with the concept of psychology which is said by Herzberg that actually what drives a person is essentially two factors, namely the Motivational factor and the hygiene or maintenance factor. The first factor, namely Motivational, is a factor that originates within a person, meaning that the twenty-eight points above are all factors that originate within a person so that they can give him enthusiasm and encouragement to carry out goals ${ }^{43}$.

43 Mirabela-Constaţa Matei dan Maria-Madela Abrudan, “Adapting Herzberg's Two Factor Theory to the Cultural Context of Romania," Procedia - Social and Behavioral Sciences, 13th International Symposium in Management: Management During and After the Economic Crisis, 221 (7 Juni 2016): 95-104, https://doi.org/10.1016/j.sbspro.2016.05.094. 
Meanwhile, extrinsic factors (originating from outside) will determine a person's motivation, such as the following seven points: 1). Prophet Muhammad recommended learning to seek knowledge (knowledge needed or Morals) 2). Good and smart friends and teachers will influence a person's learning process 3). Glorifying knowledge or books, friends, teachers and their families will lead to the blessing of knowledge 4). The strength of Islam begins first by taking care of itself 5). The perfection of knowledge can be achieved by choosing a good day as well. 6). Good ways and methods of memorizing can make it easier to memorize 7). Immorality and many sins, restlessness in the affairs of the world will cause forgetfulness, eating coriander, sour apples, seeing the cross, reading the inscriptions on the tombstone, walking among tied camels, throwing live lice on the ground, clinging to the nape head, it would all cause students to become forgetful. The similarities with previous research are that this study both sees motivation as a source and driving force for students in the learning process and student achievement results.

\section{CONCLUSION}

From the above explanation, it can be concluded that strong motivation determines learning achievement and enthusiasm for learning, the greater the motivation that students have in the learning process, the more enthusiasm for learning and their achievements will be. While motivation arises from within a person called intrinsic motivation mentioned by Imam Zarnuji, there are twenty-eight motivations. Meanwhile, there are only seven extrinsic motivations or motivations that originate from outside. Millennial generations whose learning tendencies have begun to decline because the use of technology that is not appropriately used requires a robust motivational foundation, especially the classical motivation described by Sheik Zarnuji in the Ta'lim Al-Muta'allim book

\section{REFERENCES}

Afwadzi, Benny, dan Abdul Fattah. "Pemahaman Hadits Tarbawi Burhan al Islam al Zarnuji Dalam Kitab Ta'lim al Muta'allim.” Ulul Albab 17, no. 2 (1 Januari 2017): 197-217. https://doi.org/10.18860/ua.v17i2.3831.

Al-Zarnuji, Burhanul Islam. Ta 'limul Muta alim. Surabaya: Al-Hidayah, t.t.

Andres, Hayward P. "Active teaching to manage course difficulty and learning motivation." Journal of Further and Higher Education 43, no. 2 (7 Februari 2019): 220-35. https://doi.org/10.1080/0309877X.2017.1357073.

Arifin, Zainal. "Lingkungan Pendidikan Berperan Aktif Menumbuhkan Motivasi Belajar Siswa Menurut Syaikh Al-Zarnuji, Dalam Kitab Ta'limul Muta'allim." Al Qodiri: Jurnal Pendidikan, Sosial dan Keagamaan 7, no. 2 (2014): 32-40.

Astuti, Juni, Mona Novita, dan M. Syukri Ismail. "Peningkatan Motivasi Belajar Menggunakan Contextual Teaching and Learning Di Madrasah Ibtidaiyah Swasta Raudhatul Mujawwidin Tebo." Jurnal Educative: Journal of Educational Studies 5, no. 1 (1 Juli 2020): 16-28. https://doi.org/10.30983/educative.v5i1.1630.

Barmawi, Muhammad. "Peranan Lingkungan terhadap Semangat Belajar dalam Khazanah Kitab Kuning." Edukasia Islamika, 2 Maret 2017, 134-60. http://ejournal.iainpekalongan.ac.id/index.php/edukasiaislamika/article/view/773. 
Barni, Mahyuddin. “Tantangan Pendidik Di Era Millennial." Transformatif 3, no. 1 (24 April 2019): 99-116. https://doi.org/10.23971/tf.v3i1.1251.

Brandmiller, Cornelius, Hanna Dumont, dan Michael Becker. "Teacher Perceptions of Learning Motivation and Classroom Behavior: The Role of Student Characteristics." Contemporary Educational Psychology, 11 Juni 2020, 101893. https://doi.org/10.1016/j.cedpsych.2020.101893.

Chairi, Effendi. "Pengembangan Metode Bandongan Dalam Kajian Kitab Kuning Di Pesantren Attarbiyah Guluk-Guluk Dalam Perspektif Muhammad Abid al-Jabiri." Nidhomul Haq: Jurnal Manajemen Pendidikan Islam 4, no. 1 (15 Maret 2019): 70-89. https://doi.org/10.31538/ndh.v4i1.233.

Dell'Olio, Dr. Jeanine M. M, dan Dr. Tony Donk. Models of Teaching: Connecting Student Learning with Standards. Thousand Oaks: SAGE Publications, 2007. http://public.eblib.com/choice/publicfullrecord.aspx?p=996882.

Dimyati, dan Mudjiono. Belajar dan pembelajaran. Jakarta: Rineka Cipta, 1999.

E Mulyasa. Manajemen Pendidikan Karakter. 5 ed. Jakarta: Bumi Aksara, 2016.

Hanur, Binti Su'aidah, dan Titik Widayati. "Character Building Di Abad 12 Masehi: Kajian Dan Analisis Pendidikan Akhlak Dalam Kitab Ta'lim Muta'Alim." Journal of Childhood Education 2, no. 2 (1 November 2019): 176-92. https://doi.org/10.30736/jce.v2i1.37.

Hergenhahn, B. R, dan Matthew H Olson. Theories of learning = teori belajar. Diterjemahkan oleh Triwibowo. 6 ed. Jakarta: Prenada Media Grup, 2016.

Huang, Shih-Yuan, Yi-Han Kuo, dan Hsueh-Chih Chen. "Applying Digital Escape Rooms Infused with Science Teaching in Elementary School: Learning Performance, Learning Motivation, and Problem-Solving Ability." Thinking Skills and Creativity 37 (1 September 2020): 100681. https://doi.org/10.1016/j.tsc.2020.100681.

Isnaeni, Isnaeni. "Konseling Behavioral Berbasis Kitab Ta'lim al-Muta'allim Untuk Meningkatkan Motivasi Belajar Santri Di Pondok Pesantren Tafsir Hadis Shohihuddin 2, Prapen Surabay, Jawa Timur.” Undergraduate, UIN Sunan Ampel Surabaya, 2019. http://digilib.uinsby.ac.id/30215/.

Langgulung, Hasan. Manusia dan Pendidikan. Cet ke 1. Jakarta: Pustaka Al-Husna, 1986.

Larson, Jonathon E. Educational Psychology: Cognition and Learning, Individual Differences and Motivation. New York: Nova Science Publishers, 2009. http://public.eblib.com/choice/publicfullrecord.aspx?p=3018385.

Liu, I-Fan. "The Impact of Extrinsic Motivation, Intrinsic Motivation, and Social SelfEfficacy on English Competition Participation Intentions of Pre-College Learners: Differences between High School and Vocational Students in Taiwan." Learning and $\begin{array}{lllll}\text { Motivation } & 72 & (1 & \text { November } & 2020):\end{array}$ https://doi.org/10.1016/j.lmot.2020.101675.

Ma'arif, Muhammad Anas. "Analisis Konsep Kompetensi Kepribadian Guru PAI Menurut Az-Zarnuji." $\quad$ ISTAWA 2, no. 2 (2017): $35-60$. http://journal.umpo.ac.id/index.php/istawa/article/view/624.

Maslani, Maslani, Ratu Suntiah, Yasniwarti Yasniwarti, dan Dadan Nurulhaq. "Al-Zarnuji’s Thought of Education and Its Implementation at Pesantren." Jurnal Pendidikan Islam 3, no. 2 (1 Januari 2018): 179-90. https://doi.org/10.15575/jpi.v3i2.1312. 
Matei, Mirabela-Constața, dan Maria-Madela Abrudan. "Adapting Herzberg's Two Factor Theory to the Cultural Context of Romania." Procedia - Social and Behavioral Sciences, 13th International Symposium in Management: Management During and After the Economic Crisis, $221 \quad$ (7 Juni 2016): 95-104. https://doi.org/10.1016/j.sbspro.2016.05.094.

McClelland, David C. Human Motivation. Re-Issued in this digitally printed version. Cambridge: Cambridge University Press, 2009.

Muhibbin Syah. Psikologi Pendidikan dengan pendekatan baru. 18 ed. Bandung: Remaja Rosdakarya, 2013.

Muyassaroh, Rizqiyatul. "Pengaruh Aktivitas Santri Dalam Pembelajaran Kitab Ta'lim alMuta'allim Terhadap Motivasi Belajar Agama Santri Ma'had al-Jami'ah Walisongo Semarang." Undergraduate, UIN Walisongo Semarang, 2019. http://eprints.walisongo.ac.id/9591/.

Ngalim, Purwanto. Psikologi Pendidikan. 27 ed. Bandung: Remaja Rosdakarya, 2014.

Rahman, Alfianoor. "Pendidikan Akhlak Menurut Az-Zarnuji Dalam Kitab Ta'lim alMuta'allim.” At-Ta'dib 11, no. 1 (1 Juni 2016). https://doi.org/10.21111/attadib.v11i1.647.

Ramayulis, dan Samsul Nizar. Filsafat pendidikan Islam: telaah sistem pendidikan dan pemikiran para tokohnya. Jakarta: Kalam Mulia, 2009.

Ryan, Richard M., dan Edward L. Deci. "Intrinsic and Extrinsic Motivations: Classic Definitions and New Directions." Contemporary Educational Psychology 25, no. 1 (1 Januari 2000): 54-67. https://doi.org/10.1006/ceps.1999.1020.

Salami, Nur, dan Anton Widyanto. "Etika Hubungan Pendidik Dan Peserta Didik Menurut Perspektif Pendidikan Islam Dan Pendidikan Barat (Studi Komparatif Pemikiran alZarnuji Dan Paulo Freire)." DAYAH 1, no. 2 (1 Juli 2018): 164-81. https://doi.org/10.22373/jie.v1i2.2945.

Setiawan, Agus. "Prinsip Pendidikan Karakter Dalam Islam: Studi Komparasi Pemikiran AlGhazali Dan Burhanuddin Al-Zarnuji.” Dinamika Ilmu 14, no. 1 (1 Juni 2014): 1-12. https://doi.org/10.21093/di.v14i1.4.

Siahaan, Amiruddin, Tien Rafida, dan Khairunnisa Batubara. "Influence of Madrasah Head Leadership, Motivation and Madrasah Culture on Teacher Performance in Madrasah Aliyah Model 2 Medan." Budapest International Research and Critics Institute (BIRCIJournal): Humanities and Social Sciences 3 (3 Agustus 2020): 2174-82. https://doi.org/10.33258/birci.v3i3.1150.

Sobandi, Rizki. "Pengaruh Motivasi Belajar Terhadap Hasil Belajar Bahasa Indonesia Pada Siswa Kelas Viii Mts Negeri 1 Pangandaran.” DIKSATRASLA 1, no. 2 (31 Agustus 2017): 306-10. https://jurnal.unigal.ac.id/index.php/diksatrasia/article/view/634.

Sodiman, Sodiman. "Etos Belajar Dalam Kitab Ta\&\#39;liim Al-muta\&\#39;allim Thaariq Alta\&\#39;allum Karya Imam Al-zarnuji.” Al-Ta\&\&\#39;dib 6, no. 2 (Desember 2013): 5672. https://www.neliti.com/publications/235741/etos-belajar-dalam-kitab-taliim-almutaallim-thaariq-al-taallum-karya-imam-al-za. 
Suprihatin, Siti. "Upaya Guru Dalam Meningkatkan Motivasi Belajar Siswa.” Promosi: Jurnal Program Studi Pendidikan Ekonomi 3, no. 1 (2015). https://doi.org/10.24127/ja.v3i1.144.

Suryadi, Rudi Ahmad. "Motivasi Belajar Perspektif Pendidikan Islam Klasik: Studi atas Pemikiran al-Jarnuji.” Jurnal Pendidikan Agama Islam-Ta' lim 10, no. 1 (2012).

Thohir, M. Anas, Alfina C, dan A. Dardiri. "A Comparative Study on Sheikh Az-Zarnuji Thought and Idealism in the Philosophy of Education." Episteme: Jurnal Pengembangan Ilmu Keislaman 12, no. 2 (1 Januari 2018): 411-33. https://doi.org/10.21274/epis.2017.12.2.411-433.

Tumin, Tumin, dan Ahmad Faizuddin. "Education and Character Building: Ethical Aspects of Learning from Al-Zarnūjīs Ta'līm Al-Muta'allim.” Ulumuna 21, no. 1 (1 Juni 2017): 109-28. https://doi.org/10.20414/ujis.v21i1.1180.

Ulfah, Siti Mariah. "Rekrutman Guru Dalam Manajemen Pendidikan Islam (Studi Tentang Pemilihan Guru Menurut Syeikh Az- Zarnuji Dalam Kitab Ta'limul Muta'allim Wathoriqotutta'allumi)." Al-Fikrab: Jurnal Kependidikan Islam IAIN Sulthan Thaha Saifuddin 6 (2015). https://www.neliti.com/publications/56675/rekrutman-gurudalam-manajemen-pendidikan-islam-studi-tentang-pemilihan-guru-men.

Wildemuth, Barbara M. Applications of social research methods to questions in information and library science. Westport, Conn: Libraries Unlimited, 2009.

Zed, Mestika. Metode penelitian kepustakaan. Ed. 2. Jakarta: Yayasan Obor Indonesia, 2008.

Zhou, Xiaolu, dan Ling Tian. "Study on learning motivation for innovative talents of local normal universities." Journal of Interdisciplinary Mathematics 20, no. 6-7 (3 Oktober 2017): 1401-5. https://doi.org/10.1080/09720502.2017.1382145.

Zubaedi. Desain Pendidikan karakter, Konsepsi dan Aplikasinya dalam Pendidikan. Jakarta: Kencana Prenada, 2011. 